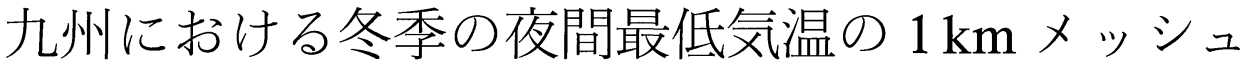 推定值と実測值の関係
}

\author{
高山 成*・早川誠而 $* *$ 小野本敏***・辻 多聞**** \\ $\left(\begin{array}{c}* \text { 鳥取大学大学院連合農学研究科 } \\ * * \text { 山口大学農学部 } \\ * * * \text { 日本気像協会九州支社 } \\ * * * * \text { 九州大学演習林 }\end{array}\right)$
}

\section{A Relationship between Estimated 1-km-Mesh Nocturnal Minimum Temperature and Observed Points Temperature over Kyushu Region in Winter}

\author{
Naru Takayama*, Seiji Hayakawa**, Satoshi Onomoto*** and Tamon Tsuil****
}

* The United Graduate School of Agricultural Sciences, Tottori University, Tottori, 680-0945 Japan
** Faculty of Agriculture, Yamaguchi University, Yamaguchi, 753-8515 Japan
*** The Headquarters in Fukuoka, Japan Weather Association, Fukuoka, 810-0052 Japan
*** Research Institute of Kyushu University Forests, Fukuoka, 811-2415 Japan

\begin{abstract}
The 1-km-mesh nocturnal minimum temperatures in winter were estimated for all of Kyushu by using variational analysis. The $1-\mathrm{km}$-mesh is not sufficient for prediction of frost occurrence and prediction of road freezing. So, a method to convert the nocturnal minimum temperatures from 1$\mathrm{km}$-mesh to 50-m-mesh was examined. The estimated deviation for $1-\mathrm{km}$-mesh nocturnal minimum temperature $\left(D T_{r-m}\right)$ was computed by subtracting $1-\mathrm{km}$-mesh nocturnal minimum temperature from observed nocturnal minimum temperature at JH (Japan Highway) weather stations. Each day from December 1, 1997 to February 28, 1998 was classified into one of five kinds of weather condition days. The properties of $D T_{r-m}$ distribution for each weather condition were investigated by rank sum test and by using GIS with a DEM (GTOPO30). The values of $D T_{r-m}$ tended to become nearly zero on rainy days, with large positive or negative values on fine days. But, in areas where flat topography predominates, the values of $D T_{r-m}$ were distributed around zero regardless of the weather conditions. On fine days, the values of $D T_{r-m}$ were large and positive in mountainous regions, and were large and negative in the West sea coastal area. The differences in the degree of localized cooling between JH weather and AMeDAS stations which depend on geographical and topographical features may cause the variation in the $D T_{r-m}$ values.

The difference of the degree of basin $\left(B D_{J-A}\right)$ was calculated from 50-m-mesh elevation data for the JH weather stations and the nearest AMeDAS stations. The values of $B D_{J-A}$ have a negative relationship to the median of $D T_{r-m}$ frequency. These results show that 1-km-mesh temperature may be convertible to 50 -m-mesh temperature by using $B D_{J-A}$.
\end{abstract}

Key words: $1-\mathrm{km}$-mesh, $50-\mathrm{m}$-mesh, Nocturnal minimum temperature, DEM, GIS.

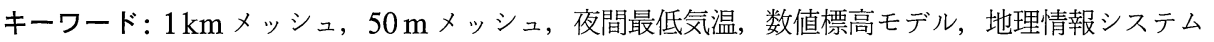

2000 年 12 月 18 日 受付, 2002 年 3 月 8 日 受理

* 現在, 鳥取大学乾燥地研究セン夕

\section{1.はじめに}

近年, メッシュ気候・気像値は特に農業分野において 重要な気象情報となっている。Yamada（1993）による 
とメッシュ気候值は公立農業関係試験研究機関の $1 / 3$ 以上が, またメッシュ気象值は約 $1 / 4$ が開発・整備して おり, 作物の生育や収量の診断・予測, 作期や作付の計 画・適地判定, 病害虫の発生予察・防除などへの利用が 図られつつある。

これまでこうしたメッシュ気候・気象値の多くは, 標 準地域メッシュシステムの 3 次メッシュすなわち $1 \mathrm{~km}$ メッシュ単位で作成されてきた。しかし，地勢が複雑な 日本では中山間地の営農現場などにおいて, $1 \mathrm{~km}$ メッ

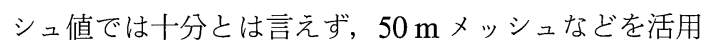
した詳細なメッシュ気象值の作成が考えられつつある (Hayakawa et al., 2001)。例えば Ohara and Ueyama （1998）は中山間地に㧊いて $50 \mathrm{~m}$ メシュ気温分布図 の作成を試みた。また，Takayama et al. (1998；1999） は晚霜害の予察を目的として, 山口県地域の力キ産地を 対象に春季夜間における局地的な冷却度合いを, $50 \mathrm{~m}$ メッシュ単位で評価することを試みた。

メッシュ気象値はこれまで雨量や気温の平年值（気候 值), あるいは年・ 月平均といった比較的長期間の気象 值が，主に農業分野における栽培適地判定や作物の生 育・収量診断といった目的に利用されてきた。これは メッシュ気象值が気象要素を客観的かつ面的に得られる 利点がある反面, 短時間スケールでのメッシュ展開の場 合推定誤差が大きくなる問題点があるためである。

Seino（1993）によると気温のメッシュ化に関して, 月 平均, 旬平均, 日平均之統計期間を変えた場合, 平均期間

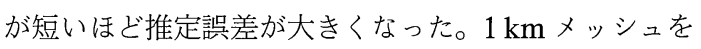
使って気温をメッシュ化する手法上の改良を検討した事 例として, Yamada（1995）は短時間スケールの気温分 布のメッシュ化手法について検討した。また, Kanno （1997）は東北地方を対象として，ヤマセと呼ばれる低 温の北東風による冷害の被害を軽減・回避するために, ヤマセ発生時における日平均気温のメッシュ化について 検討を行った。さらに Hayakawa et al. (1996) は山口 県内の数箇所の農地を対象に晚霜害の防止を目的とし

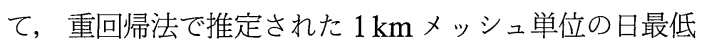
気温值を, ポイント值へと変換する手法について検討し た。

筆者らのグループは, 主に冬季, 春季に発生する霜害 の予察や路面凍結の危険度予測といった, 農業気象, 道 路気象の情報として利用可能な夜間気温のメッシュ化手 法を検討している（Takayama et al., 2000）。そこで冬 季の九州地域を対象として, AMeDAS 局に打いて得ら れた気温観測デー夕を, 客観的解析法 (Ninomiya and Akiyama, 1978；1979）により内挿し，1 kmメッシュ

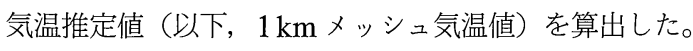

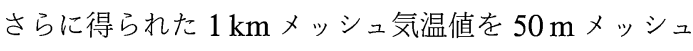
単位へと補正・変換することを検討したが，地域によっ

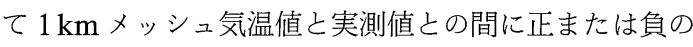
大きな差が生じうることが判明した（Takayama et al. , 2000）。こうした地域は一定の傾向を持って分布してお り, 地理的な位置, 地形, 気候・気象などの地域的な差

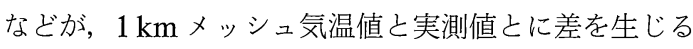
原因として考えられた。冬季の九州地域では海洋性と山 岳性, 東岸性之西岸性之いった気象特性が見られ，こう した気象特性により 15 あの小気象区に分類される (Takayama et al., 2001)。さらに九州地域の気候を調 べたDoi（1964）によると，九州内では年間を通じて冬 季の天候に特に大きな地域間差がある。すなわち, $1 \mathrm{~km}$ メッシュ気温值の補正・変換に際してはこうした地域間 の天候条件の違いを考慮して, 路線ごとに適切な方法を 見出すことが必要であると考えられる。

本論でははじめに, 高速道路沿線の定時気象観測点 ( JH 気象観測点) の夜間最低気温実測值之, その場所の $1 \mathrm{~km} メ ッ シ ュ$ 推定值による夜間最低気温（以下，メッ シュ夜間最低気温) との差 (メッシュ夜間最低気温值推 定偏差: $D T$ 值）を，高速道路沿線に㧍ける夜間最低気 温がメッシュ夜間最低気温とどの程度の差を生じるかの 指標とした。次に研究対象期間とした冬季（12月２ 月）の 90 日間について天気分類を行い, 5 種類の天気条 件ごとに $D T$ 值の相対度数分布の中央值 (以下, $D T_{M e}$ ) および標隼偏差 (以下, $D T_{S D}$ ) を調べ, 天気条件によっ て $D T$ 值の分布がごのような特徵を持つのか考察した。 さらに各天気条件における $D T_{M e}$ に差があるかを順位和 検定により調へ，その結果を $30^{\prime \prime} \times 30^{\prime \prime}$ 間隔の数值標高 モデル（DEM）と共に地理情報システム（GIS）上に展 開させた。すなわち, 天気条件ごとの $D T$ 值が観測点の 地理的（九州全域で見た位置や海抜高度）ないし地形的 (盆地地形, 平野, 丘陵など) な条件によってどのような 特徴を持つかを調べた。最後に $D T$ 值発生の要因につい て, 局地的な冷却現象の特徵や $50 \mathrm{~m}$ メッュから算出 した盆地度との関係などから考察し, $1 \mathrm{~km}$ メシュ気

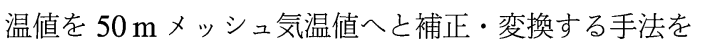
得るための基礎的資料とした。

\section{2. 解析資料および方法}

\section{1 研究対象地域および気象データ}

研究対象地域は九州地域とした。使用した気象観測 デー夕は気温の実測値として, 九州地域を走る高速自動 車道 (以下, JH 路線) に設置された, 気象観測ロボット 77 地点（以下，JH気象観測点）に打ける毎正時気温を 用いた。九州地域の地形と JH 気象観測点の位置を Fig. 


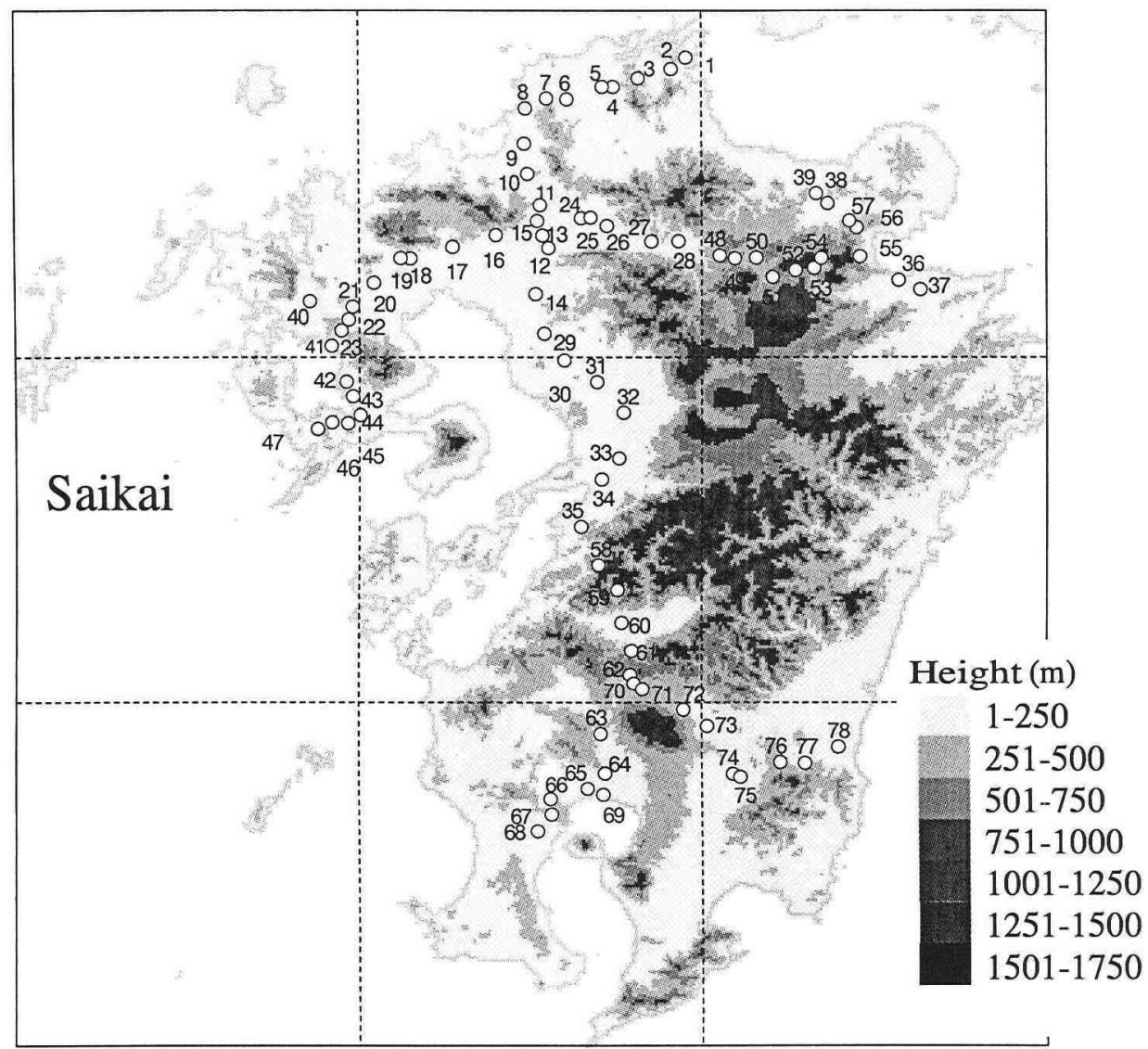

$\begin{array}{ll}\mathrm{N} 31^{\circ} & 0^{\prime} \\ \mathrm{E} 129^{\circ} & 0^{\prime}\end{array}$

Fig. 1. Location of $\mathrm{JH}$ weather stations and topographical features in Kyushu.

1 に示す。 $\mathrm{JH}$ 気象観测点の名称は後掲の Table 2 に示 し, Fig. 1 の観測点番号が Table 2 の番号および本文中 に出てくる観測点の番号に対応している。网か煩雑にな るため AMeDAS 局の位置と $100 \mathrm{~m}$ および $300 \mathrm{~m}$ の等 高線は後掲の Fig. 4 に示した。本研究では標高が 300 $\mathrm{m}$ 以上を山岳地域, $100 \mathrm{~m}$ 以上 $300 \mathrm{~m}$ 未満を山間地域, $100 \mathrm{~m}$ 未満在平野地域上定義する。九州地域の地形之 $\mathrm{JH}$ 路線の位置との関係を見ると, 九州中央部加ら東側 にかけて大規模な山岳地域が存在し, 北東部の大分道己 南部路線で山岳地域を横切っている。また九州北部では 平野地域に位置する $\mathrm{JH}$ 路線が多いが, 南部は台地地形 （シラス台地）上なっており JH 路線は概ね山間地域に 位置する。九州自動車道および隼人道は九州地域をほぼ 南北に縦断しており, 最北端の観测点である 1 (吉志)
が $\mathrm{N} 33^{\circ} 51^{\prime} 49^{\prime \prime}, \mathrm{E} 130^{\circ} 57^{\prime} 27^{\prime \prime} に$ ，また最南端の観测点 である 68 (鹿児島北 I.C.) が N $31^{\circ} 37^{\prime} 5^{\prime \prime}$, E $130^{\circ} 31^{\prime}$ $35^{\prime \prime}$ に位置する。大分白動車道・宇佐別府道および長崎 自動車道・西九州自動車道・長崎バイパスは九州北部老 東西に横断しておうり, 最東端の観測点である 37 (大分米 良 I.C.）が $\mathrm{N} 33^{\circ} 11^{\prime} 40^{\prime \prime}$ ，E131 $38^{\prime} 17^{\prime \prime}$ に，また最西端 の観测点である 47 (川平 I. C.) が $\mathrm{N} 32^{\circ} 47^{\prime} 32^{\prime \prime}$,

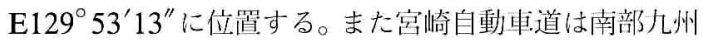
在東方向に延びている。 JH 気象観測点 77 地点のうち 43 地点は, 料金所 (I.C.) 周辺の芝地に設置されており, 残りの 34 地点については, 上下線間の芝地ないし沿線 の芝地に設置されている。観測值の代表性を考虑して, 高架橋などの建造物上に設置されている JH気象観測点 のデータは今回使用しなかった。 


\section{2 メッシュ気温値}

メッシュ気温値データとして(財)日本気象協会九州支

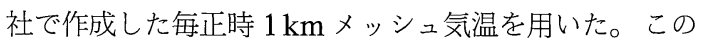
メッシュ気温值は島嶼部を含む九州地域内に位置する, 101 地点の AMeDAS（4 要素観測局）における毎正時 気温観測值を基に，AMeDAS 局のないメッシュについ て推定值で内挿する手法である。以下のような手順で毎 正時気温観測值のメッシュ化を行う。

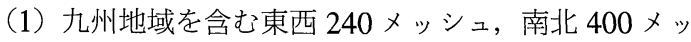
シュを座標 $(x, y)$ 上にとる。

(2) AMeDAS 局の位置する 101 個のメッシュについ て, $0.6^{\circ} \mathrm{C} / 100 \mathrm{~m}$ の気温減率で標高補正した気温の観 測値 $F_{O B S}(x, y)$ を挿入する。

（3） $\mathrm{AMeDAS}$ 局のないメッシュに 101 地点の平均值 を挿入する。

(4) 求める推定值を曲線 $F(x, y)$ として，2 つの条件す なわち, AMeDAS 地点では実測值に最む近い（条件 (1)), $F(x, y)$ が滑らかである (条件 (2)), を満たすよ うに内挿計算を行う。気温の内挿計算には变分法を応 用した客観的解析法 (Ninomiya and Akiyama, 1978; 1979）を用いた。

（5）対象地域の各メッシュの内挿計算値に標高補正を 施した值をメッシュ気温値とする。

手順 (4) に打いて条件 (1) 抢よび条件 (2)を満たすため には，式（1）および（2）をそれぞれ最小にするように 曲面の設定を行う。

$$
\begin{aligned}
& \alpha\left\{F(x, y)-F_{O B S}(x, y)\right\}^{2} \\
& \beta\left\{\left(\frac{\partial}{\partial x} F(x, y)\right)^{2}+\left(\frac{\partial}{\partial y} F(x, y)\right)^{2}\right\}
\end{aligned}
$$

ただし， $\alpha: F(x, y)$ と $F_{O B S}(x, y)$ の差に関する重み, $\beta$ : 滑らかさに関する重みである。

\section{3 メッシュ夜間最低気温值推定偏差}

日界を 9 時として夜間（17 時〜翌朝 9 時）の最低気 温について, JH 気象観測点の夜間最低気温実測値と メッシュ夜間最低気温との差を, メッシュ夜間最低気温 值推定偏差として次式のように定義する。

$$
D T_{r-m}=T_{r}-T_{m}
$$

ここで, $D T_{r-m}:$ メッシュ夜間最低気温值推定偏差 $\left({ }^{\circ} \mathrm{C}\right)$,

$T_{r}: \mathrm{JH}$ 気象観測点に抢ける夜間最低気温の実測値 $\left({ }^{\circ} \mathrm{C}\right), T_{m}: \mathrm{JH}$ 気象観測点を含む $1 \mathrm{~km}$ メッシュのメッ シュ夜間最低気温 $\left({ }^{\circ} \mathrm{C}\right)$ である。

はじめに 77 地点の $\mathrm{JH}$ 気象観測点における $D T_{r-m}$ (以下, $D T$ 值) を, 1997 年 12 月 1 日から 1998 年 2 月 28 日の 90 日について算出した。次に JH 気象観測点ご とに算出した $D T$ 值の相対度数分布を求め, その中央值 および標準偏差を，各 $\mathrm{JH}$ 気象観測点における夜間最低
気温の実測值とメッシュ夜間最低気温との差を評価する 指標とした。すなわち， $D T$ 值相対度数分布の中央値を $D T_{M e}$ として, JH 気象観測点付近における夜間最低気 温がメッシュ夜間最低気温より低いか高いかの傾向を調 べた。さらに $D T$ 值相対度数分布の標準偏差を $D T_{S D}$ と して, JH 気象観測点における $D T$ 値出現のばらつき程 度の評価を行った。 $D T_{M e}$ が 0 に近い值でかっ $D T_{S D}$ が 小さい程, 気温実測值とメッシュ気温值との差が少ない 場所であると言える。

\section{4 天気条件の分類}

それぞれの $\mathrm{JH}$ 気象観測点に㧍ける $D T$ 值の出現が, 天気条件によりどのような傾向を示すかを明らかにする ため, 対象期間の 90 日間を晴天, 曇天, 雨天, 冬型, そ の他の 5 種類の天気条件に分類した。天気条件の分類に は下関, 佐賀, 大分, 熊本, 宮崎, 鹿児島の各地方気象 台, 福岡管区気象台, 長崎海洋気象台に抢ける, 18 時汃 ら翌日 6 時までの天気を考慮した。分類の手順は以下の 通りである。

（1）当日9 時の地上天気図で西高東低の冬型気圧配置 となっており， $850 \mathrm{hPa}$ の気温がー $5^{\circ} \mathrm{C}$ 以下となって いる場合，すなわち寒気移流場となっている日を冬型 に分類する。

（2）各 JH 気象観測点汃ら最寄りの気象台（福岡管区気 象台, 長崎海洋気象台, 佐賀, 大分, 熊本, 宮崎, 鹿 児島の各地方気象台) に打ける夜間天気概況（18 時～ 翌日 6 時）から, 晴天, 曇天, 雨天を分類する。ここ で, 晴天は晴れ, 晴れ一時曇り, 晴れ時々曇り, 薄曇 りの場合である。量天は曇り, 曇り一時晴れ, 曇り 時々晴れの場合である。雨天は雨, 曇り時々雨, 晨り 一時雨, 量り後一時雨の場合である。

（3）気象概況の晴れ後曇りおよび昰り後晴れについて は，気温の低下具合加ら晴天と最天に分類する。

（4）晴天条件に分類された日について，前日 15 時から 当日 9 時までの気象衛星ひまわりの赤外画像より, 雲 が多い場合は量天にする。

（5）晴天条件に分類された日について，夜間の気温の低 下が極めて少なく放射冷却が顕著でない場合をその他 に分類する。これはひまわりの赤外画像では確認でき ない低層雲がある日や風が強い日に相当する。

（6）晴れ, 曇り, 雨が混在し, 晴天, 曇天, 雨天, 冬型 のいずれの天気条件にも分類するのが困難な日を，そ の他に分類する。

\section{$2.5 D T$ 值分布の有意差検定}

77 地点の $\mathrm{JH}$ 気象観測点それぞれにおいて, 各天気 条件における $D T$ 值分布の傾向に差があるのかを調べ た。すなわち, 77 地点の $\mathrm{JH}$ 気象観測点において 5 種類 
の天気条件の組み合わせ 10 通りについて, 母集団の $D T_{M e}$ に差があるのか順位和検定を用いて有意水準 95\% で調べた。天気条件日 1 における $D T$ 値を $x_{11}$, $\mathrm{x}_{12}, \cdots x_{1 n}$, 同じく天気条件日 2 を $x_{21}, x_{22}, \cdots x_{2 n}$ とし, 2 つのデー夕群を合わせて昇順に順位を付けていく。 デー夕数が少ないデー夕群の順位和を検定統計量として 両側検定を行った。

\section{6 地形データ}

Fig. 1 に示したように地理情報システム（GIS）上に 数值標高モデル (DEM) を展開し，77 地点の $\mathrm{JH}$ 気象 観測点および九州地域の離島などを除く AMeDAS 局 86 地点を重站合わせた。使用した GIS 解析ソフトは ArcView GIS Version 3.0a (ESRI 社製)，また DEM データはU.S. Geological Survey（USGS）による GTOPO30を用いた。GTOPO30 は緯度・経度方向に $30^{\prime \prime} \times 30^{\prime \prime}$ 間隔の標高グリッドから構成されており, こ のうち E100 N40 のデータセットから, 九州地域付近 の範囲である南西端が $\mathrm{N} 30^{\circ} 40^{\prime}, \mathrm{E} 129^{\circ} 00^{\prime}$, 北東端が $\mathrm{N} 34^{\circ} 00^{\prime}, \mathrm{E} 132^{\circ} 00^{\prime}$ までの東西 $360 \times$ 南北 400 個の メッシュデータを切り出した。切り出した標高グリッド デー夕は GIS ソフト上で, 10 進数経緯度座標を平面の $\mathrm{X}, \mathrm{Y}$ 座標として描画させた。さらに $\mathrm{JH}$ 気象観測点抒 よび AMeDAS 局を WGS84 系で 10 進数緯度経度を 用いて番地付けを行い，GTOPO30 の上に重㸚合わせ た。

まず，JH 気象観測点および AMeDAS 局の地理的な 位置打よび抢打まかな地形条件を GTOPO30 から読み 取り, $D T$ 值の地域的な分布やその発生要因について考 察した。次に盆地地形は局地的な冷却の発達に重要な影 響を与えるため, 盆地度は冷却しやすい地形条件を表す 指標であると考えた。そこで JH 気象観測点および AMeDAS 局周辺のより微細な地形条件を調べるため, 盆地度 $(B D)$ （Takayama et al., 2001）を算出した。

$$
B D=H_{R}-H_{C}
$$

ここで $H_{R}$ はメッシュ拡張数 $\mathrm{R}$ の周辺メッシュの平 均標高 $(\mathrm{m}), H_{C}$ は観測点があるメッシュの標高 $(\mathrm{m})$ で ある。標高デー夕には国土地理院による数值地図 $50 \mathrm{~m}$ メッシュ（標高）を用いた。メッシュ拡張数 $\mathrm{R}$ は観測点 があるメッシュに隣接する 8 メッシュを $\mathrm{R}=1$ の，さら にその外側にある 16 メッュを $\mathrm{R}=2$ の周辺メッシュ とする。

\section{7 局地冷却度の算出}

ある観測点 $\mathrm{j}$ に扔ける気温と対象地域の平均的な気温 との偏差をある期間について平均し，この值を観測点 $\mathrm{j}$ に打ける地理的効果による冷却度 $G C(j)\left({ }^{\circ} \mathrm{C}\right)$ とする。 このとき観測点 $\mathrm{j}$ が観測日 $\mathrm{i} に G C(j)$ よりどの程度冷
えたかを, 局地冷却度 (Sumino, 1961) として次式から 算出した。

$$
\begin{aligned}
& L C(i, j)=T(i, j)-T A M(i)-G C(j) \\
& \operatorname{TAM}(i)=\frac{1}{m} \sum_{j=1}^{m}\{T(i, j)\} \\
& G C(j)=\frac{1}{n} \sum_{i=1}^{m}\{T(i, j)-T A M(i)\}
\end{aligned}
$$

ここで, $L C(i, j)$ は $\mathrm{i}$ 日の $\mathrm{j}$ 地点における局地冷却度 $\left({ }^{\circ} \mathrm{C}\right), T(i, j)$ は $\mathrm{i}$ 日の $\mathrm{j}$ 地点に打ける夜間最低気温 $\left({ }^{\circ} \mathrm{C}\right), n$ はデー夕日数, $m$ は観測点数である。TAM $(i)$ は $\mathrm{i}$ 日における対象地域の平均気温之考え, $T A M(i)$ の 算出に使う観測点が対象地域の中で地理的に均等に分布 していることが望ましい。AMeDAS 局は約 $21 \mathrm{~km}$ 間 隔でなるべく均等に分布するよう設置されている。そこ で $L C(i, j)$ (以下， $L C$ 值）の算出に際して AMeDAS 局の場合は，Fig. 4 に示した 86 地点の AMeDAS 局の $T(i, j)$ 加 $m=86$ として計算し, JH気象観測点の場 合は AMeDAS 局 86 地点 $+\mathrm{JH}$ 気象観測点 $(m=87)$ として計算した。 $G C(j)$ は観測点ごとに $T(i, j)$ と $T A M(i)$ との偏差を, 本研究の対象期間 90 日 $(n=90)$ で平均した。 $G C(j)$ の值には経緯度, 海陸分布などの観 測点の地理的な位置や標高差といった, 地理的効果によ る気温差が主に反映される。

\section{3. 結果および考察}

\section{1 天気条件と $D T$ 值分布の特性について}

はじめに 77 地点の $\mathrm{JH}$ 気象観測点において 5 種類の 天気条件ごとに算出した， $D T_{M e}$ の相対度数分布を Fig. 2 に示す。ただし図を見やすくするためにその他の天気 条件は除いた。Fig. 2 から分加るように $D T_{M e}$ は雨天日 に最も 0 付近に集中するような分布を呈した。また，

Fig. 3 に $D T_{S D}$ の相対度数分布を 0.3 刻みで示した。 $D T_{S D}$ は雨天日において最あ小さい値で分布しており, $D T$ 值の分布にばらつきが最も小さいと言える。従っ て, JH気象観測点に㧍ける夜間最低気温実測值とメッ シュ夜間最低気温との差は雨天日において最む小さくな る傾向にあり,メッシュ気温値が現地の気温を精度良く 反映していると考えられる。 $D T_{M e}$ 打よび $D T_{S D}$ の 天気条件ごとの分布から算出した，標準偏差 $D T_{M e S D}$, $D T_{S D S D}$ を Table 1 に示す。 $D T_{M e S D}$ の值は雨天日が最 む小さく冬型, 曇天, その他, 晴天の順に大きくなった。 一方, $D T_{S D S D}$ の值は $D T_{M e S D}$ と同様に雨天日において 最む小さかったが，晴天日，曇天日，冬型日の間で大き な差はなかった。以上の結果加推察して, 雨天条件下 では局地的な冷却現象があまり発達せず気温の空間分布 


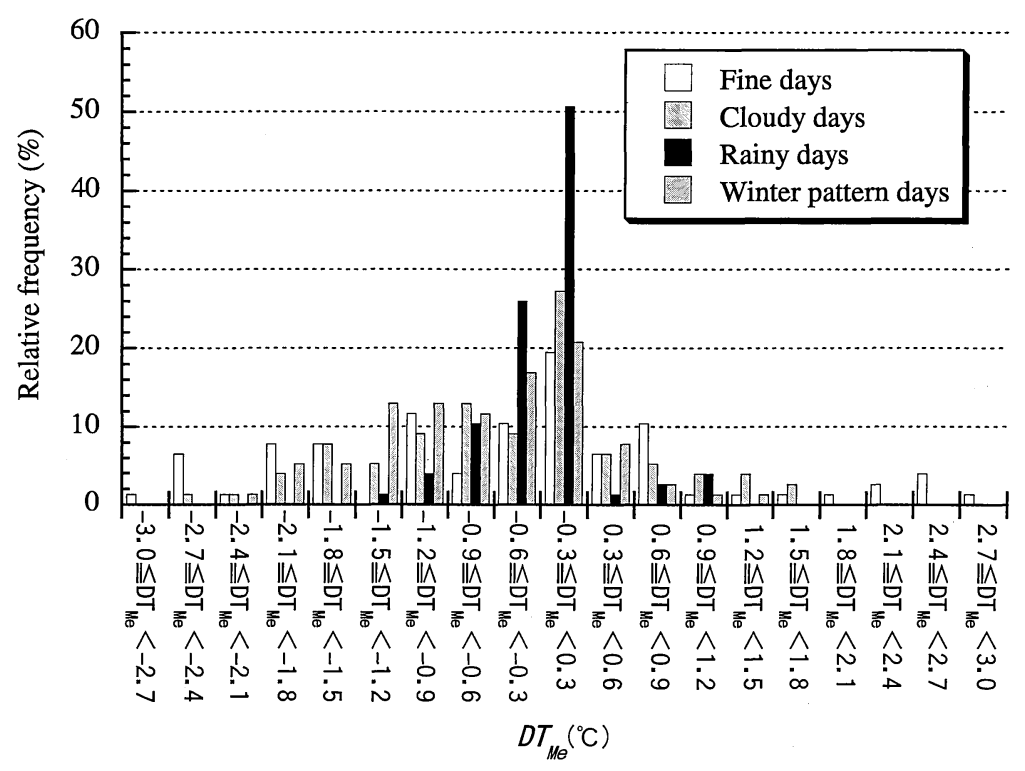

Fig. 2. Relative frequency distribution of $D T_{M e}$ under each weather condition.

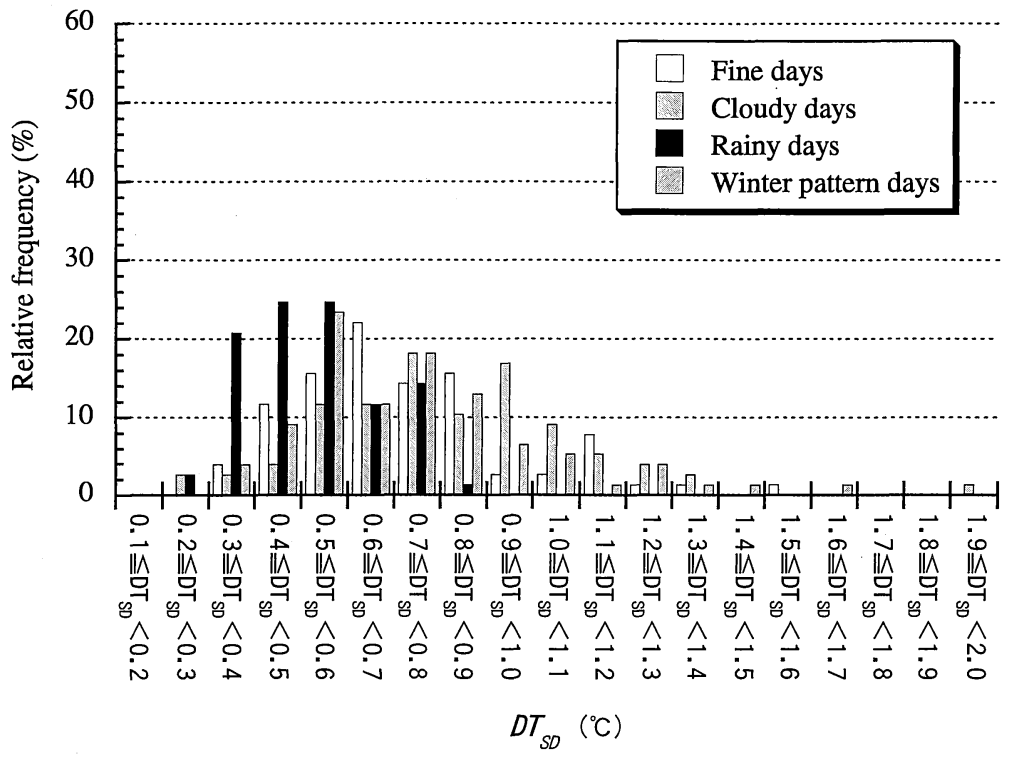

Fig. 3. Relative frequency of $D T_{S D}$ under each weather condition.

の連続性が良くなるため, AMeDAS 観測值の空間内挿 によるメッシュ展開手法が有効に機能すると考えられ る。逆に晴天条件下では局地的な冷却現象が発達しやす く気温の空間分布の局地性が強くなるため，場所によっ ては実際の夜間気温とメッシュ気温値との差が大きくな ると考えられる。
Table 1. Standard deviations calculated from $D T_{M e}$ and $D T_{S D}$ for all $\mathrm{JH}$ weather stations under each weather condition.

\begin{tabular}{rcc}
\hline Weather condition & $D T_{M e S D}$ & $D T_{S D S D}$ \\
\hline Fine days & 1.36 & 0.24 \\
Cloudy days & 0.94 & 0.28 \\
Rainy days & 0.47 & 0.15 \\
Winter pattern days & 0.75 & 0.26 \\
Other days & 1.04 & 0.38 \\
\hline
\end{tabular}




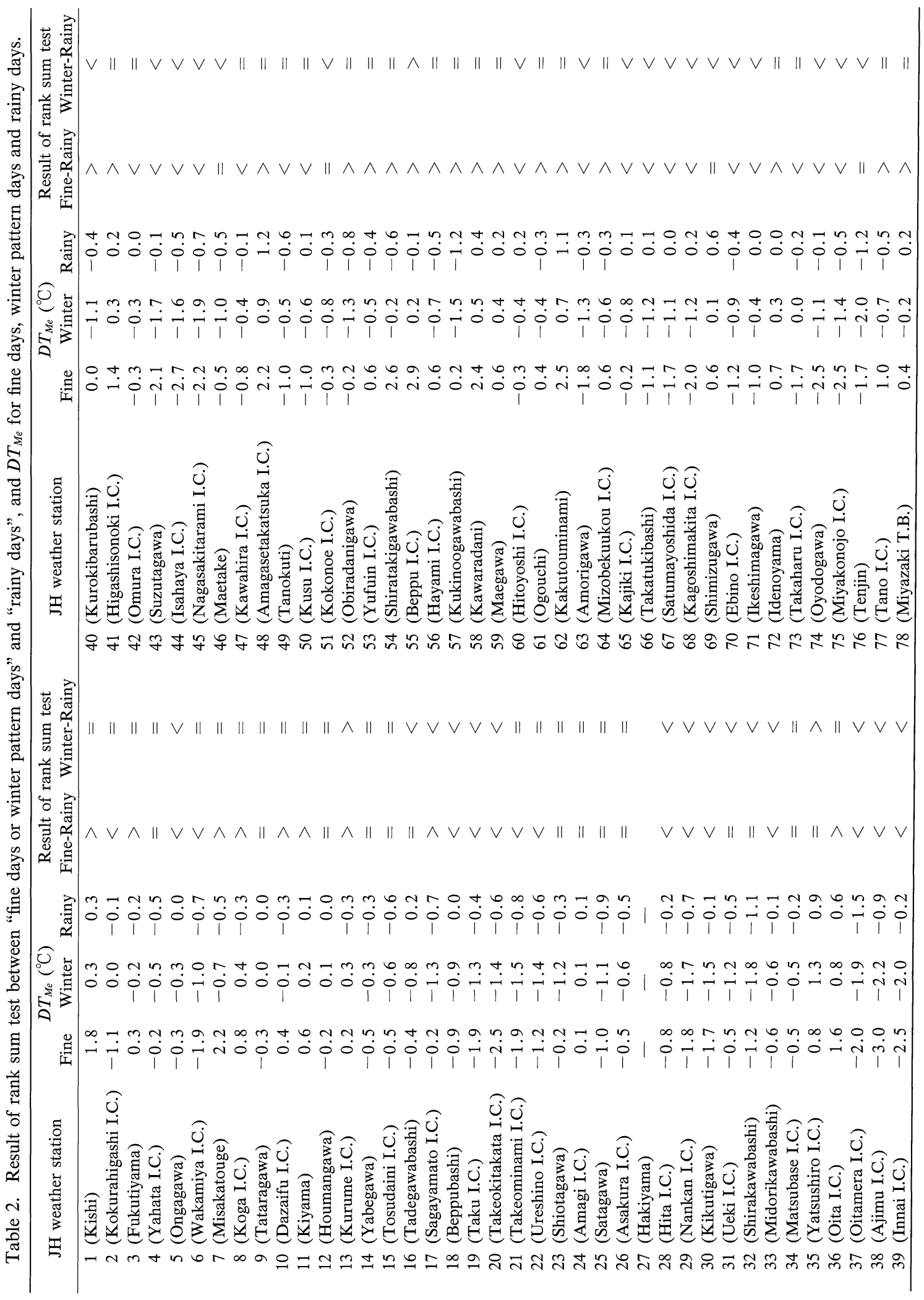




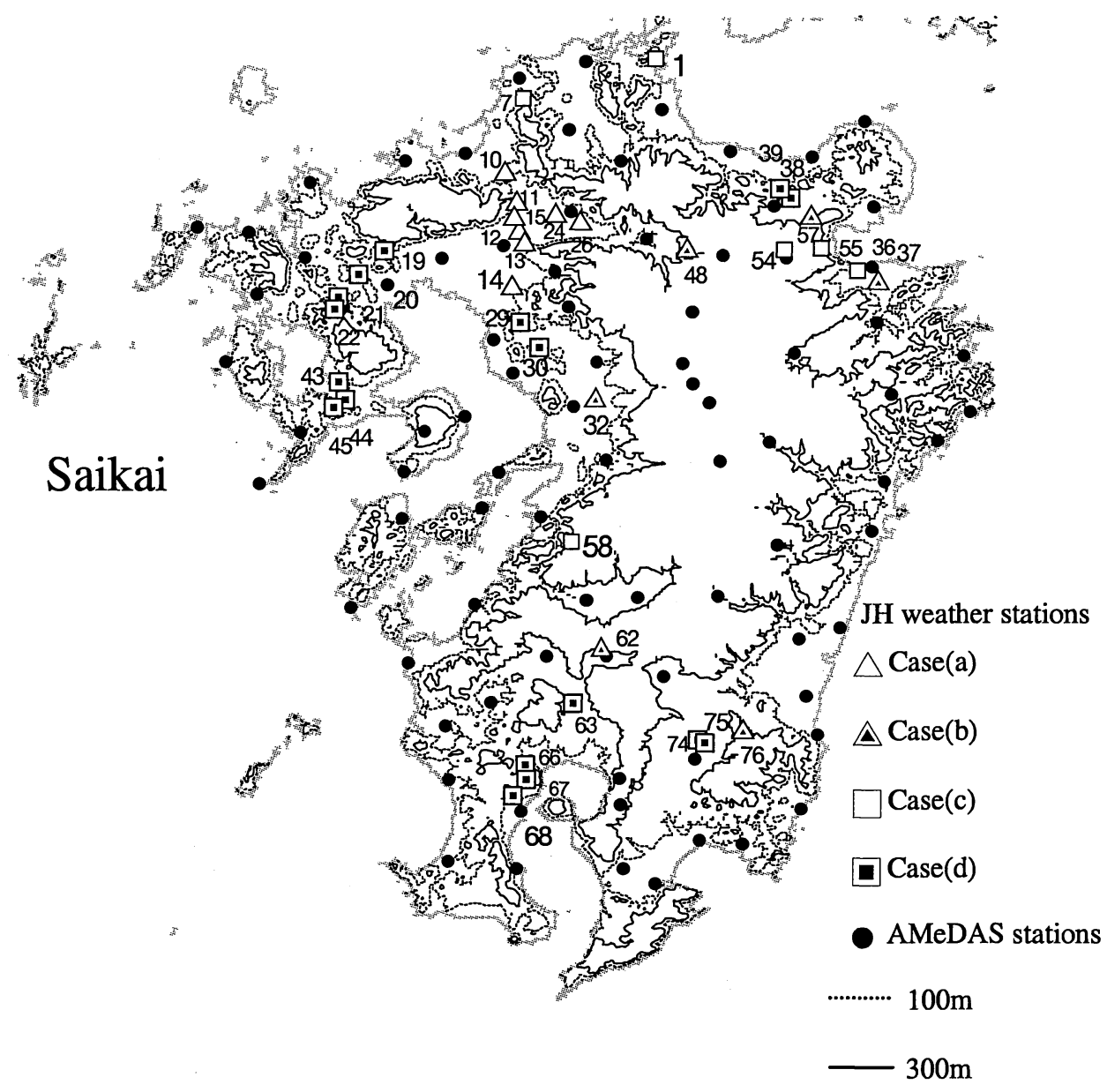

Fig. 4. Classification of JH weather stations into four cases. Case (a) $-0.5 \leqq D T_{M e} \leqq 0.5$ and $D T_{S D} \leqq$ 0.6. Case (b) In rainy days, $D T_{M e} \leqq-1.0$ or $D T_{M e} \geqq 1.0$. Case (c) As a result of rank sum test, $D T_{M e}$ for fine days is larger than for rainy days, and $D T_{M e} \geqq 1.5$ on fine days. Case (d) As a result of rank sum test, $D T_{M e}$ for fine days is smaller than for rainy days, and $D T_{M e} \leqq-1.0$ for both fine and windy days.

\section{$3.2 D T$ 值分布の地域的な傾向および特徵}

\subsubsection{DT 值分布の傾向による場合分け}

各 $\mathrm{JH}$ 気象観測点に打ける天気条件ごとの $D T_{M e}$ を比 較するために, 順位和検定を用いて 5 種類の天気条件ご との $D T$ 值分布に抢ける中央值 $\left(D T_{M e}\right)$ に，有意水準 95\% で差があるかを調べた。はじめに $D T$ 值の分布に ばらつきが最む小さい雨天日を基準として考え，雨天日 と晴天日, 雨天日と最天日, 雨天日と冬型日の間で検定 を行った。次に晴天日, 曇天日, 冬型日それぞれの間で 検定を行い, 最後に $D T_{M e}$ の值と併せて天気条件と $D T$ 值分布の地理的な傾向との関係について考察した。各 $\mathrm{JH}$ 気象観測点における晴天日之雨天日, 冬型日之雨天 日についての検定結果抢よび $D T_{M e}$ を Table 2 に示す。

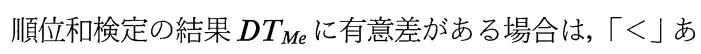
るいは「>」の記号を記し，有意差がない場合は「=」 の記号を記した。各天気条件における $D T_{M e}$ 打よび $D T_{S D}$ の分布および各 $\mathrm{JH}$ 観測点に扔ける順位和検定の 結果を, GIS 解析ソフト上に重㸚合わせ, $D T$ 值分布の 地域的な傾向とその特徵について考察した。 $D T_{M e}$, $D T_{S D}$ の指標之順位和検定結果を用いて, $D T$ 値分布の 傾向と特徵を 4 つのパターンに分類したところ, $D T$ 値 分布の傾向に関して地域的な特徵が見出された。すなわ ち, 天気条件に関係なく $D T$ 值分布にばらつきが小さい 地域 $\{$ Case（a)\}，すべての天気条件において $D T$ 値の 分布にばらつきが大きい地域 $\{$ Case (b) \}, $D T$ 值の分布 が特に晴天日に正の傾向にある地域 $\{$ Case (c) $\}, D T$ 值 
の分布が特に晴天日や冬型日に負の傾向にある地域 \{Case (d)\}である。それぞれの Case の分類方法は以下 の通りである。

Case（a） 77 地点の JH 気象観測点における 90 日間の $D T$ 值の分布について, $-0.5 \leqq D T_{M e} \leqq 0.5$ 功 $D T_{S D} \leqq 0.6$

Case (b) 雨天日において $D T_{M e} \leqq-1.0$ あるいは $D T_{M e}$ $\geqq 1.0$

Case（c）晴天日に $D T_{M e}$ が雨天日よりあ大きくかつ $D T_{M e} \geqq 1.5$

Case（d）晴天日に打ける $D T_{M e}$ が雨天日よりあ小さく かつ，晴天日抢よび冬型日に $D T_{M e} \leqq-1.0$

それぞれの Case に分類された JH 観測点の分布を Fig. 4 に示す。

\subsection{2 天気条件に関係なく $D T$ 值分布にばらつきが 小さい地域}

天気条件に関係なく $D T$ 值分布にばらつきが小さい Case（a）として分類されたのは，9（多々良川）から 15 (鳥栖第二 I.C. ), 24 (甘木 I.C. ) に至る 8 地点を含む区 間であった。この路線は筑紫平野から筑後平野にかけた 平坦な地形であり, 8 地点すべてが平野地域に位置して いた。 $1 \mathrm{~km}$ メッシュ気温值が $1 \mathrm{~km}$ 四方の平均的な気 温之考えると, $1 \mathrm{~km}$ 四方よりあ微小な局地的現象に支 配されうる場所では，必ずしも現場における気温を反映 していない可能性がある。しかし，平坦な地形が広範囲 に広がる平野地域では気温分布が微小な地形に影響され る割合が少ないため, JH 路線と AMeDAS 点の気温に 類似性があり, AMeDAS 観測值の空間内挿による気温 推定が有効であると考元られる。

\subsection{3すべての天気条件において $D T$ 値の分布にば らつきが大きい地域}

雨天日は先に述べたように $D T$ 值の分布に, ばらつき が最む小さい天気条件である。しかし Fig. 2 を見ると 雨天日にも $D T$ 值の分布に, 正または負の大きな值をと る傾向がある観測点が数䇢所存在し, これらは Case （b）として分類された。Case（b）の JH 気象観測点のう ち $D T_{M e} \leqq-1.0$ すなわち, 雨天日に $D T$ 値の分布が負 の大きな值をとる傾向にあったのは，32 (白川橋)，37 (大分米良 I.C.), 57 (久木野尾川橋), 76 (天神トンネ ル）の 4 地点である。逆に $D T_{M e} \geqq 1.0$ すなわち $D T$ 值 の分布が正の大きな値をとる傾向にあったのは, 48 (天ヶ瀬高塚 I.C.)，62 (加久藤南) でいずれも山岳地域 に位置していた。これらの 6 地点は天気条件に関係な $く$, 夜間最低気温実測值とメッシュ夜間最低気温とに差 が大きい観測点である。これら 6 地点は特定地域に偏ら ず九州全域に点在しており, うち 4 地点が I.C. 以外に

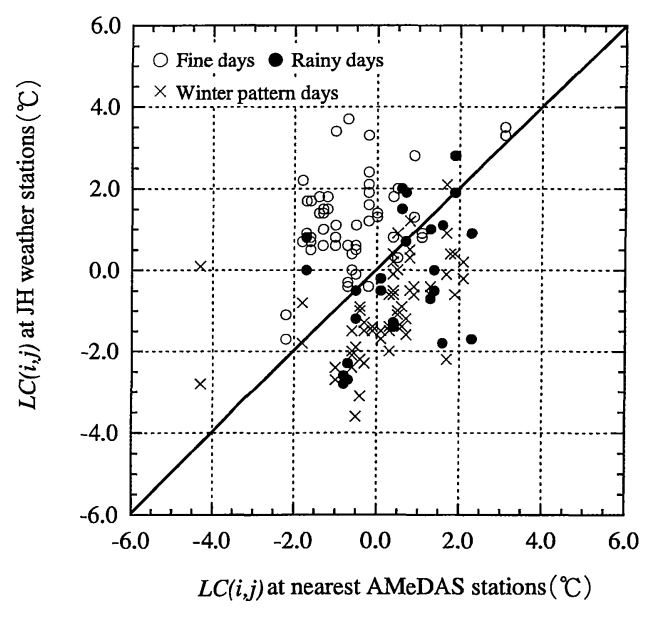

Fig. 5. Relationship between " $L C(i, j)$ at No. 54 and No. $55 \mathrm{JH}$ weather stations" and " $L C(i, j)$ at their nearest AMeDAS stations".

設置された観測点である。62 (加久藤南), 76 (天神トン ネル）はトンネルの入口付近に，また 32 (白川橋)，57 (久木野尾川橋) は河川近くに設置されている。これらの $\mathrm{JH}$ 気象観測点はすべての天気条件においてトンネルな どの周辺地形の影響を受け, 特異的な気温分布を呈して いる可能性がある。

\subsubsection{DT 值の分布が正の傾向にある地域}

Case（c）には 6 地点が分類された。ただし，既に Case（b）として分類した 48 （天ヶ瀬高塚 I.C.）と 62 （加久藤南）は，条件を満たしたが Case（c）に加えな かった。Case（c）の6 地点のうち 54 (白滝川橋), 58 （川原谷）は山岳地域に，55（別府 I.C.）と 7 (見坂峠) は山間地域に位置していた。山岳・山間地域は平野地域 と比較して地形が複雑であり, 逆転層の影響などあ加 わって冷却現象の発達度合いや発生の傾向が大きく異な る。54 (白滝川橋), 55 (別府 I.C.) と, それぞれの JH 観測点加ら最も距離が近い AMeDAS 局（以下，近傍 AMeDAS）における局地冷却度との関係を Fig. 5 に示 す。 JH 気象観測点では晴天日において $L C$ 值が正の值 となることが多く, 地理的効果による冷却量 (以下, $G C$ 值）よりあ冷え込んでいない。逆に近傍 AMeDAS では 局地冷却度が負の值をとることが多く, $G C$ 值よりあ冷 え込む観測点であったことが分かる。また, 南部の山岳 地域に位置する 58 (川原谷) に扔いても同様の傾向が得 られた。山岳地域の路線である大分道付近を拡大した図 を Fig. 6 に示す。JH気象観測点は山地の中腹斜面に多 く位置しているが, 山岳・山間地域の AMeDAS 局の 多くは盆地に位置していることが分かる。AMeDAS 観 


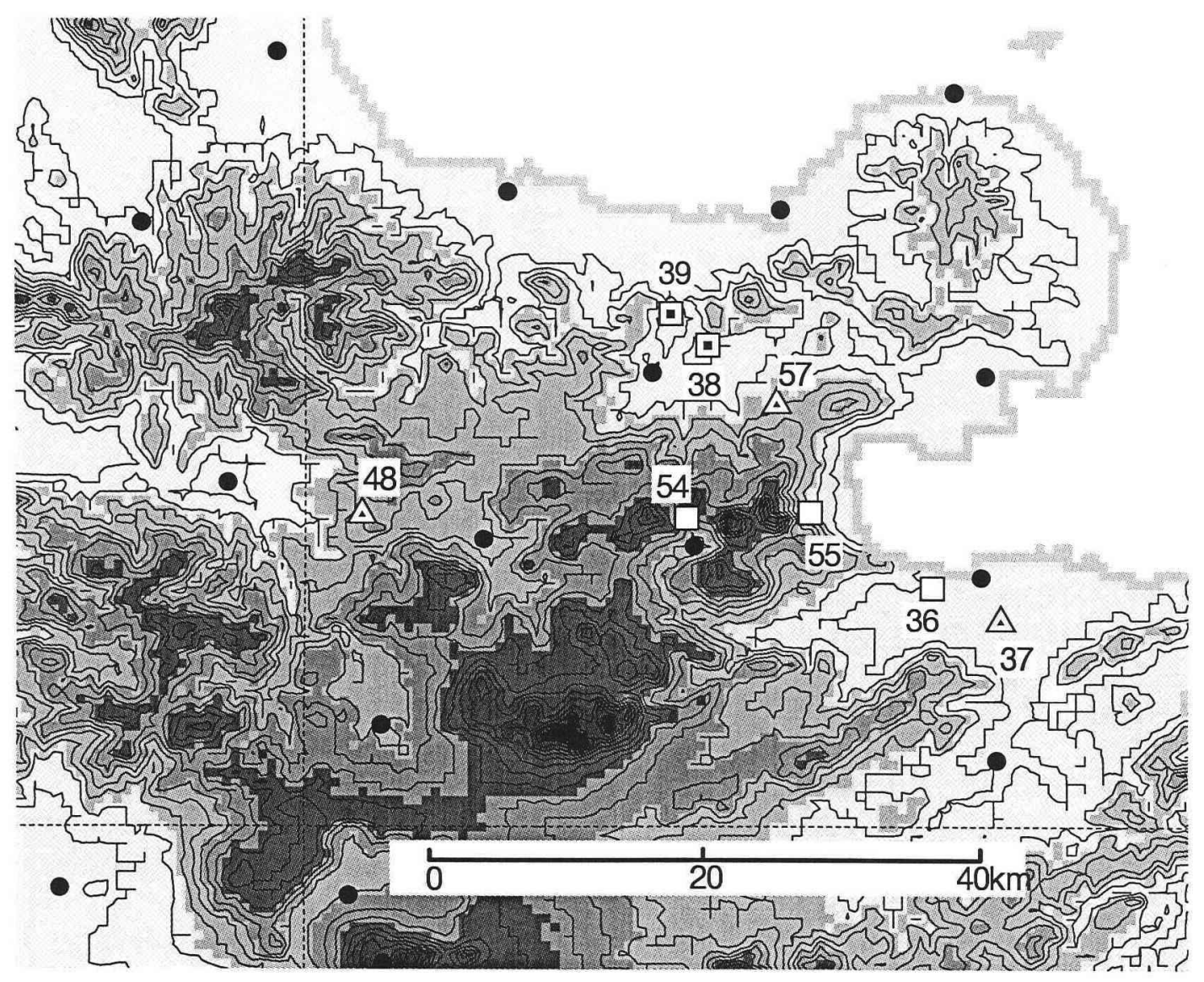

Fig. 6. Topographical features and locations of $\mathrm{JH}$ weather stations in the vicinity of Oita Highway.

測值の空間内㨂により父温值のメッシュ展開を行った場 合, 近傍 AMeDAS に求ける観测值は対象メッシュの 予測值に最も強い影響を及ぼす。山岳・山間地域におい ては地形が複雉で気温分布の局地性が強いため, 刘象地 域之 AMeDAS 観測点の立地条件の違いにより冷え込 み万に大きな差がある。実際, 九州地域の最低気温の地 理的分布特性を調べた Hayakawa et al. (1985) による と, 最低気温の出現確摔から求めたエントロピは山岳地 帯で大きくなって抢り, 最低気温の出現の仕方に地形が 複雑に関与していた。このため局地的な冷却現象が卓越 するような天気条件下では, AMeDAS 観測值の内捜に よるメッシュ気温值が現場の父温を十分に捉え切れない 上考えられる。また， 48 (天ヶ瀨高塚 I.C. ) と 62 (加久 藤南) は 3.2 .3 に述べたように, 雨天日にも $D T_{M e}$ が正 の大きな値となる傾问があった。しかし，これらの JH 気像観測点は晴天日に $D T_{M e}$ がさらに大きくなってお り, 周辺地形からの影響に加えて AMeDAS 局との立 地条件の違いが，このような $D T$ 值分布の特徴を生じる
要因となっていると考えら机る。

また，山岳・山間地域では冬型日と雨天日とで $D T_{M e}$ に有意差が認められた観測点が少なからた。これは型 気庄配置や雨天日の気温は，スケールの大きい場の現象 が卓越し，局地的な泠却現象が現われにくいため上思わ れる。

\subsubsection{DT 值の分布が負の傾向にある内陸地域}

Case（d）に分類された JH 気象観测点は，晴天日や冬 型日において夜間最低気温の実测值がメッシュ夜間最低 気温よりかなり低くなる傾问老持ち, 九州西部の佐賀, 辰崎, また南部の鹿児島などの路線に多く分布してい た。ただし，既に Case（b）に分類した 37 (大分米良I. C.), 76 (天神トンネル) は除いた。

はじめに，夜間気温降下量を 5 時の気温一前日 19 時 の気温と定義して，21（武雄南 I.C.）における $D T$ 值と の関係を調べたものを Fig. 7 に示す。Fig. 7 に示した ような，夜間気温降下量とDT 值との間に $95 \%$ 有意で 正相関が得られた $\mathbf{J H}$ 父像観測点は， $D T_{M e}$ が睛天日, 


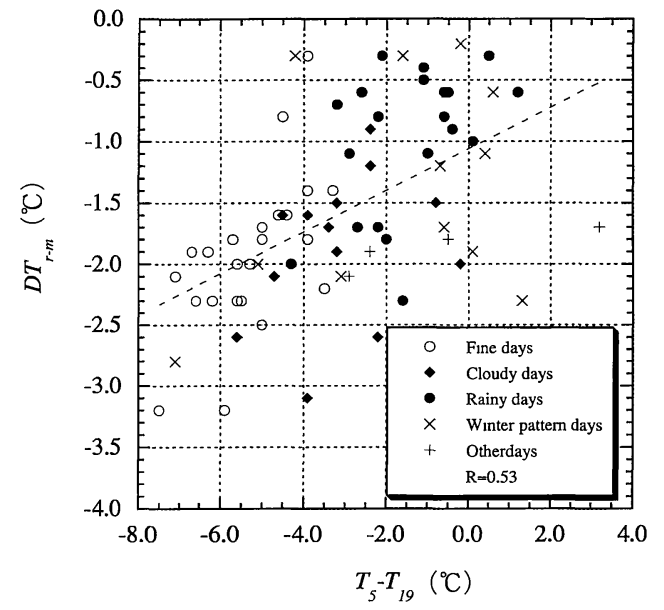

Fig. 7. Relationship between decreases of temperature for the night $\left(T_{5}-T_{19}\right)$ and deviation of temperature estimated by $1-\mathrm{km}$-mesh $\left(D T_{r-m}\right)$ at No. $21 \mathrm{JH}$ weather station.

冬型日などにおいて雨天日よりあ負の大きな値をとった 観測点にほぼ対応していた。特に九州北西部の 19 (多久 I.C.)，20（武雄北方 I.C.）や九州南部の台地上にある 74 (大淀川)，75（都城 I.C.）など内陸の地域に位置す る地点では, 夜間気温降下量と $D T$ 值との間に高い正の 相関が得られた。すなわち，大部分が晴天日に現われる 冷却量が大きい（夜間気温降下量が小さい）日において, $D T$ 值が負の大きな值となっていることを示唆する。

次に $\mathrm{JH}$ 気象観測点之近傍 AMeDAS における局地 冷却度の関係について，19（多久 I.C.）および 20 (武雄 北方 I.C.）の場合を Fig. 8 (a) に，63 (天降川)，74 (大淀川), 75 (都城 I.C.) の場合を Fig. 8 (b) に示す。 これらの $\mathrm{JH}$ 気象観測点では特に晴天日の $L C(i, j)$ が負の大きな值となっていたが, 近傍 AMeDAS の $L C(i, j)$ あ類似した值で分布していた。また, Case (d) の うち北東部の 38 （安心院 I.C.）や 39 （院内 I.C.）で屯 同様の傾向が得られた。しかし，上記の 7 地点における $G C(j)$ を近傍 AMeDAS の $G C(j)$ と比較したところ, 63 (天降川) 以外の 6 地点に打いて近傍 AMeDAS よ りあ $\mathrm{JH}$ 観測点における $G C(j)$ は低い值となってい た。すなわち, $L C(i, j)$ 分布の傾向は類似しているが, $\mathrm{JH}$ 観測点は近傍の AMeDAS 局上りも潜在的に冷え込 む場所にあり, 気温の偏差は晴天日に特に顕著となると 考えられる。このことは 3.1 に述べた, $D T$ 值分布の ばらつきが雨天日に最む小さく晴天日に最む大きかった 事実とも合致する。Fig. 6 には北東部のみ地形図を 示したが, Case (d) に分類された九州北西部の 19 (多久
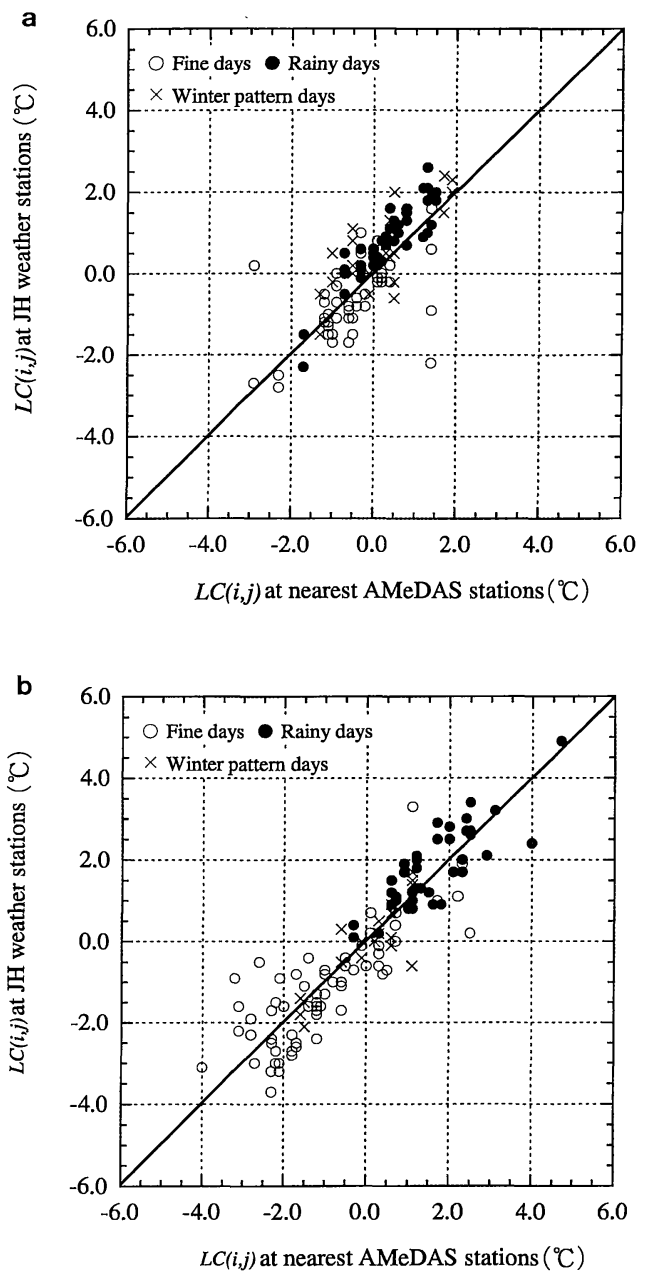

Fig. 8. Relationship between $L C(i, j)$ at several $\mathrm{JH}$ weather stations and $L C(i, j)$ at their nearest AMeDAS stations. (a) Inland plain area in the northwest part of Kyushu including No. 19 and No. $20 \mathrm{JH}$ weather stations. (b) Highland area in the south part of Kyushu, including No. 63, No. 74 and No. $75 \mathrm{JH}$ weather stations.

I.C. ）21（武雄南 I.C.），中央部の 29 (南関 I.C.)，30 (菊池川), 北東部の 38 (安心院 I.C.), 39 (院内 I.C.) は, 平野地域の中でも周囲を山間地域に囲まれた盆地地 形である。こうした地形条件では冷気が滞留しやすいた め, 変分法による気温の空間内挿値より低温な地域が点 在していると推察される。従って, 観測点が位置する場 所の潜在的な冷え込みやすさを評価することにより, メッシュ気温值を補正できる可能性がある。このことに 関しては 3.3 に述べる。 

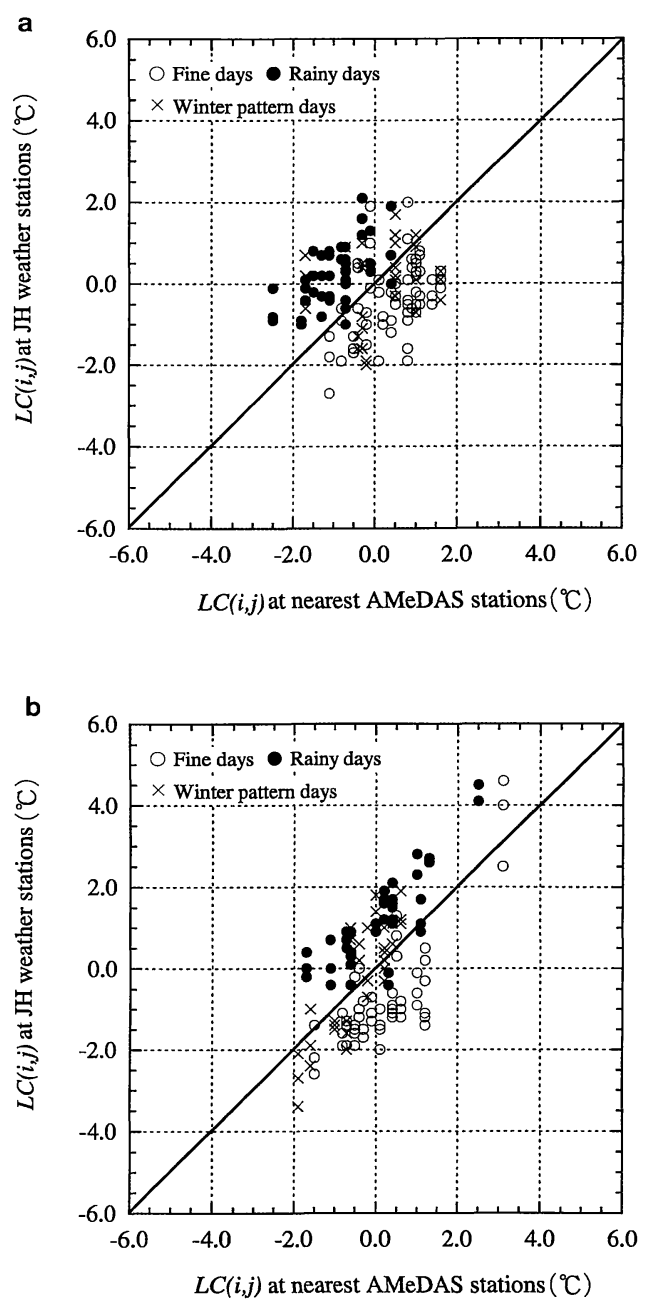

Fig. 9. Relationship between $L C(i, j)$ at several JH weather stations and $L C(i, j)$ at their nearest AMeDAS stations. (a) Coastal area in the west part of Kyushu, including No. 43, No. 44 and No. $45 \mathrm{JH}$ weather stations. (b) Coastal area in the south part of Kyushu, including No. 66, No. 67 and No. $68 \mathrm{JH}$ weather stations.

\subsection{6 $D T$ 值の分布が負の傾向にある沿岸地域}

次に Fig. 4 に示した Case (d) に分類された JH 気象 観測点のうち, 九州西部沿岸地域の 43 (鈴田川), 44 (諌 早 I.C. )，45（長崎多良見 I.C.）抒よび南部沿岸地域の 66 (高附橋), 67 (薩摩吉田 I.C.)，68 (鹿児島北 I.C.), における, 近傍 AMeDAS と JH 気象観測点における 局地冷却度の関係を Fig. 9 (a), (b) に示す。これらの 路線では近傍 AMeDAS と JH 気象観測点とで局地冷 却度の傾向が異なり, 晴天日には近傍 $\mathrm{AMeDAS}$ で $G C$
值よりも冷えず, 逆に $\mathrm{JH}$ 気象観測点では $G C$ 值より冷 え込む傾向にある。西海沿岸は Fig. 4 から分かるよう に特に海岸の入り組んだ複雑な地形であり, AMeDAS 局の多くは沿岸部に位置し観測点数む少ない。晴天夜間 条件下では内陸の盆地地形などは冷え込みやすいが，沿 岸地域や高台地形などでは局地冷却があまり発達しない （最近の例では Takayama et al., 1999）。また, 西海沿 岸地域は対馬海流の影響で海岸に近い地域ほど温暖であ るため（Doi, 1964），西海の海岸までの距離が JH 気象 観測点より屯短い AMeDAS 局周辺における冷え込み 方は, JH 気象観測点がある場所と比べて顕著でないと 考えられる。従って, 沿岸地域に偏った AMeDAS 観測 值を用いて夜間最低気温をメッシュ化した場合, JH 気 象観測点に扔いてそれほど冷却が顕著でなくても，DT 值の分布が特に大きな負の値となる傾向を持つと考えら れる。

\section{3 地形条件亡 $D T$ 值との関係}

3.2.4 から 3.2.6 までに述べたように, $D T$ 值の分布 が晴天日や冬型日に正または負の大きな值をとる傾向に ある地域が存在し, これは局地的な冷却現象の発達の仕 方が JH 沿線と AMeDAS 局周辺とで異なるためであ ることが,一つの大きな要因であると推察された。局地 的な冷却現象は一般に放射冷却が卓越する晴天夜間にお いて, 盆地や谷といった冷気が滞留しやすい地形で発達 する。そこで JH 気象観測点と近傍 AMeDAS 局の盆 地度との差を盆地度偏差 $\left(B D_{J-A}\right)$ と定義し, $\mathrm{JH}$ 気象観 測点周辺での局地的な冷却が AMeDAS 局周辺と比較 してどの程度発生しやすいかの指標とした。 $B D_{J-A}$ は次 式で示される。

$$
B D_{J-A}=B D_{J}-B D_{A}
$$

ここで $B D_{J-A}$ は盆地度偏差 $(\mathrm{m}), B D_{J}, B D_{A}$ はそれ ぞれ JH 気象観測点メッシュ, JH 気象観測点の近傍 AMeDAS 局メッシュにおける盆地度（m）である。盆 地度偏差は盆地度のメッシュ拡張数 $\mathrm{R}=1 \sim 60$ につい て算出し，值が大きい程 JH 気象観測点周辺において局 地的な冷却が発達しやすいと考えられる。

Fig. 4 に示したCase (b)，(c)，(d) に分類された 29 地点の $\mathrm{JH}$ 気象観測点における盆地度偏差と, 晴天日お よび冬型日における $D T_{M e}$ との関係を調べた。その結 果, 北部の日本海沿岸に近い 1 (吉志), 7 (見坂峠), 西 海沿岸地域の 43 (鈴田川), 44 (諌早 I.C.) , 45 (長崎多 良見 I.C.）を入れた場合には，95\%有意で相関が得ら れなかった。これらの JH気象観測点においては $D T$ 值 発生の要因が, 3.2.4や3.2.5で述べたような盆地の冷 却効果よりも，3.2.6 に述べたような海洋の影響などが 大きいためと思われる。また, 南部の山岳地帯にある 58 


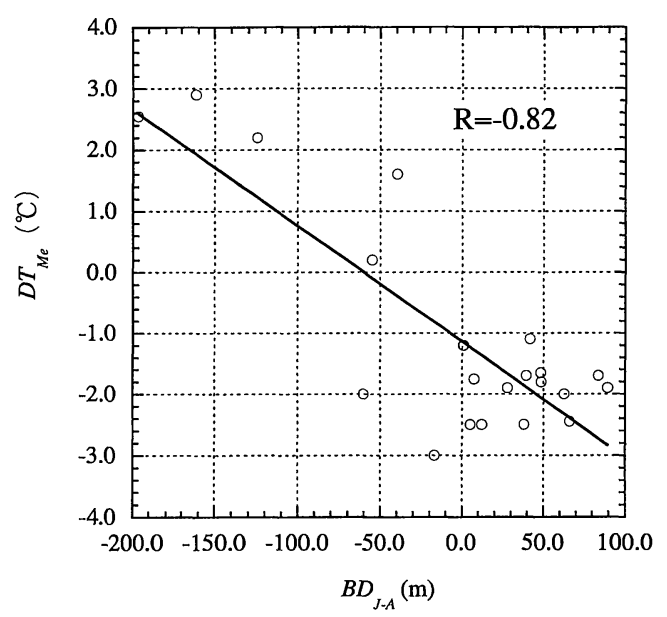

Fig. 10. Relationship between $B D_{J-A}$ and $D T_{M e}$ at $22 \mathrm{JH}$ weather stations.

（川原谷）および 62 (加久藤南)を入れた場合も, 盆地度 偏差と $D T_{M e}$ とに有意な相関が得られず, 南部山岳地帯 にある路線については再検討の余地があると思われる。 上記の 7 地点 $(1,7,43,44,45,58,62)$ を除く 22 地点の $\mathrm{JH}$ 気象観測点に抢ける, 晴天日と冬型日の盆地 度偏差と $D T_{M e}$ との関係を調べた。晴天日では盆地度の メッシュ拡張数が $\mathrm{R}=24 \sim 60$ の場合に, また冬型日で は $\mathrm{R}=28 \sim 60$ の場合に, 盆地度偏差と $D T_{M e}$ との間 に $95 \%$ 有意で負相関が得られたが，冬型日では $\mathbf{R}=$ -0.60であまり相関は高くなかった。Fig. 10 には, 最 あ強い相関が得られた拡張数 $\mathbf{R}=51$ の盆地度偏差之晴 天日に打ける $D T_{M e}$ との関係を示した。盆地度偏差と $D T_{M e}$ とに一定の相関関係が得られたことから, $50 \mathrm{~m}$ メッシュ標高から算出した盆地度により $\mathrm{JH}$ 気象観測点 および AMeDAS 局の地形による冷却効果を考慮する ことで， $D T$ 值分布が特に正または負の大きな值をとる 傾向にある $\mathrm{JH}$ 気像観測点について, $1 \mathrm{~km}$ メッシュ気 温値をより細密に変換できる可能性が得られた。また, 海洋の影響が $D T$ 值発生の大きな要因と思われる西海 沿岸地域などについては, 陸度, 海岸距離といった地形 因子による变換手法について今後検討したい。

\section{4. まと め}

冬季の九州地域を対象として，夜間最低気温における

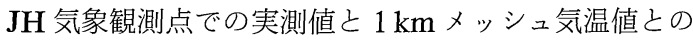
差 (メッシュ夜間最低気温値推定偏差: $D T$ 値) が, どの ような出現の特徵を持つか 5 種類の天気条件について 調べた。さらに $D T$ 值が生じる原因について，局地的な 冷却現象や $50 \mathrm{~m}$ メッシュ標高から算出した盆地度との
関係から考察し, $1 \mathrm{~km}$ メッシュ気温値を $50 \mathrm{~m}$ メッシュ 単位へと補正・変換できるか検討を行った。その結果, 以下のようなことが明らかとなった。

1）九州地域に招ける夜間最低気温分布のばらつきは雨 天<冬型＜量天＜その他＜晴天の順に大きくなり， $D T$ 值の分布のばらつきも同様の順に大きくなる。

2）平坦な地形が広範囲に広がる平野地域では, 気温の 空間的分布にかなりの連続性があり, 变分法による気 温推定手法が有効である。しかし，山岳・山間地域は 複雑な地形条件を有するため気温の空間的な分布の局 地性が強い。例えば，山岳の斜面などで局地的な冷却 の発達が顕著でない場所で, 近傍の AMeDAS 局が 山間の盆地などに設置されている場合は， $D T$ 值の分 布が正の大きな值となる傾向がある。また，放射冷却 や冷気の滞留などによる局地的な冷却現象が発達しや すい内陸の平野地域では, 近傍の AMeDAS よりも 冷却が顕著となり, $D T$ 值の分布が負の大きな值とな る傾向がある。

3）九州の西海沿岸地域には AMeDAS 局数が少なく, 立地も夜間温暖な沿岸に偏っている。そのため晴天日 において, 局地的冷却の発達が顕著にならない $\mathrm{AMe}$ DAS 局の観測值の影響が，夜間気温のメッシュ展開 に際して相対的に大きくなる。その結果， $D T$ 值の分 布がより大きな負の值をとる傾向がある。

4）盆地度偏差 $B D_{J-A}$ と $D T_{M e}$ との間には $95 \%$ 有意で負

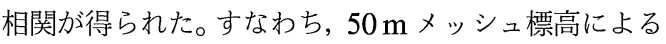
盆地度を用いて, 高速道路周辺之 AMeDAS 局周辺 との冷却に関する地形効果を考慮することにより， 1 $\mathrm{km}$ メッシュ気温値を $50 \mathrm{~m}$ メッシュ単位へと変換で きる可能性が示された。

今回の解析で明らかとなった $D T$ 值の出現傾向之そ の発生要因に基づいて, 現行の $1 \mathrm{~km}$ メッシュ気温值を より細かい空間スケールへと変換する手法について，今 後より詳細な検討を行いたい。

\section{謝辞}

本研究において使用した気解観測デー夕を提供してい ただいた, 日本道路公団九州支社の関係者の方々に感謝 します。

\section{References}

Doi, K., 1964: Climate of Kyushu. In Climate of Kyushu (ed. by Kuraishi, Y.). Fukuoka district meteorological observatory, Fukuoka, pp. 14-17 （土井謙二, 1964: 九州の気候. 福岡管区気象台, pp. 14-17).

Hayakawa, S., Maki, T. and Suzuki, Y., 2001: In- 
strumentation and control in agricultural field. Yokendo, Tokyo, pp.151-157 (早川誠而・真木太 一・鈴木義則, 2001: 耕地環境の計測・制御. 養賢堂, pp. 151-157).

Hayakawa, S., Takayama, N. and Kawamura, H., 1996: The advanced utilization system for meteorological mesh information allowing for the 21st century. In The food production and agricultural environment of the 21st century (ed. by Eguchi, $\mathrm{H}$., Kimura, K. and Hayakawa, S.). The Society of Agricultural Meteorology of Japan, Tokyo, pp. 99-108（早川誠而・高山 成・河村宏明, 1996: 21 世紀に向けたメッシュ気像情報の高度利用システム。 21 世紀の食糧生産と農業環境, 日本農業気象学会, pp. 99-108).

Hayakawa, S., Wakimizu, K., Yamamoto, K., Iwaya, T. and Motoda, Y., 1985: Studies on the climate in Kyushu district on the geographical distribution of minimum air temperature in Kyushu district. Agric. Meteorol. Kyushu, 21, 43-47 (早 川誠而・脇水健次 - 山本 香 - 岩屋照実 ・元田雄四 郎, 1985: 九州地域の最低気温の地理的分布特性. 九 州の農業気象, 21, 43-47).

Kanno, H., 1997: Estimation of daily-mean air temperatures on a $1 \mathrm{~km}^{2}$ mesh during the occurrence of a Yamase wind. J. Agric. Meteorol., 53, 11-19.

Ninomiya, K. and Akiyama, T., 1978: Objective analysis of heavy rainfalls based on radar and gauge measurements. J. Meteorol. Soc. Jpn., 56, 206-210.

Ninomiya, K. and Akiyama, T., 1979: Objective analysis of rainfall distribution and displacement of heavy rainfall area based on radar and gauge measurements for surveillance of heavy rainfalls. TENKI, 26, 19-26.

Ohara, G. and Ueyama, H., 1998: Estimation of 50-m-mesh temperature over local region. In Proceedings of the 98th Meeting of the Society of Agricultural Meteorology of Japan. The Society of Agricultural Meteorology of Japan, Tokyo, pp. 104105 （大原源二・植山秀紀，1998：局地の $50 \mathrm{~m}$ メッ シュ気温分布図の試作. 日本農業気像学会 1998 年度 全国大会講演要旨, 日本農業気象学会, pp. 104-
105).

Seino, H., 1993: An estimation of distribution of meteorological elements using GIS and AMeDAS data. J. Agric. Meteorol., 48, 379-383.

Sumino, M., 1961: On the estimation of minimum air temperature in Miyagi Prefecture. TENKI, 8, 226-230.

Takayama, N., Hayakawa, S. and Kawamura, H., 1998: Research of mesh-temperature during the night in Yamaguchi Prefecture. In Proceedings of the 98th Meeting of the Society of Agricultural Meteorology of Japan. The Society of Agricultural Meteorology of Japan, Tokyo, pp. 106-107（高山 成・早川誠而・河村宏明, 1998: 山口県に抢ける夜間 気温のメッシュ値について。 日本農業気象学会 1998 年度全国大会講演要旨, 日本農業気象学会, pp. 106107).

Takayama, N., Hayakawa, S. and Kawamura, H., 1999: Analysis of localized cooling for prediction of frost damage occurrence by using 50-m mesh topographical data. J. Agric. Meteorol., 55, 235246.

Takayama, N., Hayakawa, S. and Onomoto, S., 2000: Research of estimated deviation for $1-\mathrm{km}$ mesh minimum temperature over Kyushu region in winter. In Proceedings of the 2000th Meeting of the Society of Agricultural Meteorology of Japan. The Society of Agricultural Meteorology of Japan, Tokyo, pp. 78-79 (高山 成・早川誠而・河村宏明, 2000: 九州地域に打ける冬季の $1 \mathrm{~km}$ メッシュ気温値 の推定偏差について。 日本農業気象学会 2000 年度全 国大会講演要旨, 日本農業気像学会, pp. 78-79).

Takayama, N., Hayakawa, S. and Onomoto, S., 2001: Meteorological classification and characteristics of cooling at night over Kyushu Region in Winter. $\sim$ GIS Analysis . TENKI., 48, 535-545.

Yamada, K., 1993: Situation of meteorological data and its intelligence system.-On summarizes of questionnaires to the prefectures-. Agric. Inf. Res., 2, 1-15.

Yamada, K., 1995: Short-term air temperature on a regional scale and its estimation with a nocturnal cooling model. J. Agric. Meteorol., 51, 345-354. 